\title{
The cytotoxic and antifungal activities of two new sesquiterpenes, malfilanol $A$ and $B$, derived from Malbranchea filamentosa
}

\author{
Daigo Wakana ${ }^{1}$, Tomoo Hosoe ${ }^{1}$, Hiroshi Wachi ${ }^{1}$, Takeshi Itabashi ${ }^{1}$, Kazutaka Fukushima ${ }^{2}$, Takeshi Yaguchi ${ }^{2}$ \\ and Ken-ichi Kawai ${ }^{1}$
}

The Journal of Antibiotics (2009) 62, 217-219; doi:10.1038/ja.2009.9; published online 13 February 2009

Keywords: antifungal activity; cytotoxic activity; Malbranchea filamentosa; malfilanol; sesquiterpene

Fungi of the genus Malbranchea belong to the family Onygenaceae and are taxonomically close to human and animal pathogenic fungi. ${ }^{1}$ These facts prompted us to investigate the chemical constituents of Malbranchea fungi. We recently reported the isolation and structural characterization of 4-benzyl-3-phenyl-5H-furan-2-one as a vasodilator, malfilamentosides A and B as furanone glycosides and malbrancheosides A-D as triterpene glycosides, from the fungus Malbranchea filamentosa IFM41300. ${ }^{2-4}$ Further purification of extracts of rice cultivated by the above fungus allowed us to isolate two new sesquiterpenes, designated malfilanol A (1) and B (2). Characterization of their structures, cytotoxic activities and antifungal activities are described in this paper.

The molecular formula of malfilanol A (1) (Figure 1) was determined as $\mathrm{C}_{15} \mathrm{H}_{24} \mathrm{O}_{3}$ (four degrees of unsaturation) by high-resolution chemical-ionization mass spectrometry (HRCI-MS). Detailed analyses of the ${ }^{1} \mathrm{H}$ - and ${ }^{13} \mathrm{C}$-NMR spectra and HMQC correlations of $\mathbf{1}$ revealed the presence of one exchangeable proton, three methyl units, five methylene units, two methine units, two quaternary carbons (one of which is oxygenated) and one olefine unit with an attached carboxylic acid $\left(\delta\right.$ 172.6). These data accounted for the ${ }^{1} \mathrm{H}$ - and ${ }^{13} \mathrm{C}$ NMR resonances and required the compound to be bicyclic. Interpretation of the ${ }^{1} \mathrm{H}-{ }^{1} \mathrm{H}$ COSY data led to the identification of two isolated proton spin systems corresponding to C-2-C-3 and C-5-C-7, including the branched C-9-C-11 chain subunits of structure $\mathbf{1}$. The heteronuclear multiple bond coherence (HMBC) correlations (Figure 2) from $\mathrm{H}_{3}-12$ to $\mathrm{C}-1, \mathrm{C}-2, \mathrm{C}-11$; from $\mathrm{H}_{3}-13$ to $\mathrm{C}-4, \mathrm{C}-5$, C-14; from $\mathrm{H}_{3}-14$ to C-3, C-13; from $\mathrm{H}_{2}-2$ to C-4, C-11; from $\mathrm{H}_{2}-3$ to C-5; from $\mathrm{H}_{2}-5$ to C-13, C-7; from $\mathrm{H}-7$ to C-6, C-9, C-11, C-15; and from $\mathrm{H}_{2}-9$ to $\mathrm{C}-7, \mathrm{C}-8, \mathrm{C}-10, \mathrm{C}-11$ enabled the determination of structure 1 .
Analysis of NOESY data (Figure 3 ) and ${ }^{1} \mathrm{H}$ NMR $J$-values enabled assignment of the relative configuration of malfilanol A (1). The coupling constant observed between H-6 and H-11 $(2.8 \mathrm{~Hz})$ indicated these two protons to be in a cis configuration. NOESY correlations of $\mathrm{H}-6$ both with $\mathrm{H}_{3}-14$ and with one proton of $\mathrm{H}_{2}-10\left(\delta_{\mathrm{H}} 1.41\right)$ revealed that all these protons have a syn orientation. Further, the NOESY correlation between another proton of $\mathrm{H}_{2}-10\left(\delta_{\mathrm{H}} 1.77\right)$ and $\mathrm{H}_{3}-12$ was used to place these protons on opposite faces of the molecule against $\mathrm{H}-6$, thereby establishing the relative configuration of malfilanol A (1).

The elemental composition of malfilanol B (2) was determined as $\mathrm{C}_{16} \mathrm{H}_{26} \mathrm{O}_{3}$ (four degrees of unsaturation) on the basis of HRCI-MS and NMR data, which weighs 14 mass units higher than 1 . Analysis of ${ }^{1} \mathrm{H}$ - and ${ }^{13} \mathrm{C}$-NMR data revealed the presence of a methoxy group $\left(\delta_{\mathrm{C}}\right.$ $\left.51.4, \delta_{\mathrm{H}} 3.69\right)$ in 2 , instead of a hydroxyl group attached to C-15. On the basis of this consideration, the structure of 2 was presumed to be the methyl ester of 2 . Further, methylation of $\mathbf{1}$ with $\mathrm{CH}_{2} \mathrm{~N}_{2}$ provided 2 , which was identical to the naturally occurring one, including the optical rotation (CD spectra). Therefore, malfilanol B (2) was identified as the methyl ester of 1 , and was established to have the same stereochemistry at C-1, C-6 and C-11 as $\mathbf{1 .}$

Antifungal activity was determined using the paper disk method, as described in a previous study. ${ }^{5}$ Malfilanol A (1) and malfilanol B (2) showed specific antifungal activities against Cryptococcus neoformans (the diameters of the inhibition circles for $\mathbf{1}$ and $\mathbf{2}$ were 15 and $13 \mathrm{~mm}$, respectively), but there was no antifungal activity against Aspergillus fumigatus, A. niger or Candida albicans, at $50 \mu \mathrm{g}$ per disk. Malfilanol A (1) and B (2) were tested for cytotoxic activities against human umbilical vein endothelial cells (HUVEC) and A549 human lung cancer cells. Malfilanol A (1) and B (2) inhibited the cell proliferation of HUVEC with IC $_{50}$ values of 14.6 and $19.8 \mu \mathrm{M}$ respectively, while

${ }^{1}$ Faculty of Pharmaceutical Sciences, Hoshi University, Tokyo, Japan and ${ }^{2}$ Research Center for Pathogenic Fungi and Microbial Toxicoses, Chiba University, Chiba, Japan Correspondence: Dr T Hosoe, Faculty of Pharmaceutical Sciences, Hoshi University, Ebara 2-4-41, Shinagawa-ku, Tokyo 142-8501, Japan. E-mail: hosoe@hoshi.ac.jp

Received 22 September 2008; accepted 21 January 2009; published online 13 February 2009 


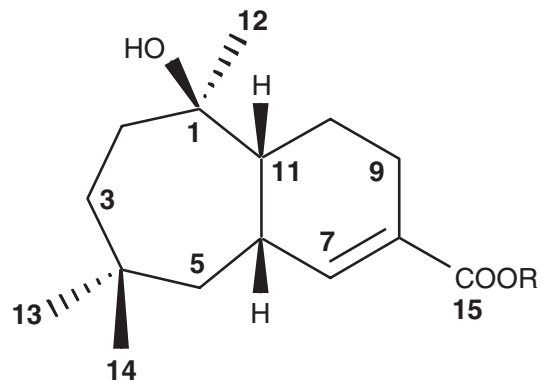

Malfilanol A (1) $R=H$

Malfilanol B (2) $\mathrm{R}=\mathrm{CH}_{3}$

Figure 1 Structures of malfilanol A (1) and B (2).

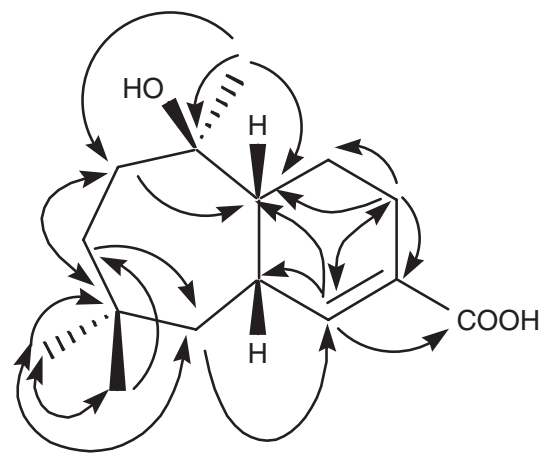

Figure 2 Important HMBC correlations of malfilanol A (1).

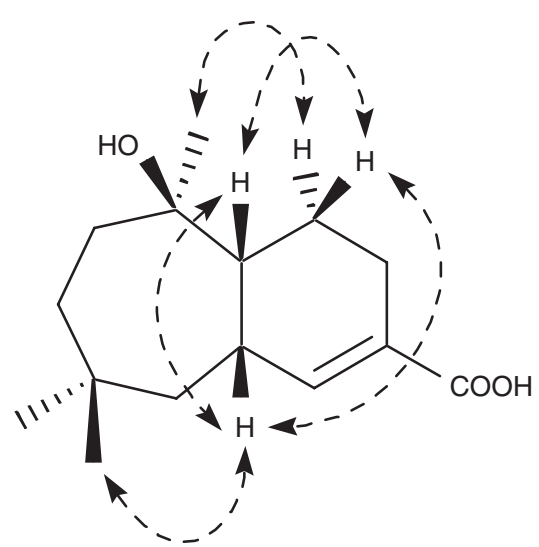

Figure 3 Important NOESY correlations of malfilanol A (1).

malfilanol B (2) inhibited proliferation of A549 cells with an $\mathrm{IC}_{50}$ value of $7.8 \mu \mathrm{M}$. Malfilanol A (1) showed no inhibition of A549 cell proliferation at $79.4 \mu \mathrm{M}$.

\section{EXPERIMENTAL SECTION}

\section{General}

Melting points were determined on a micro-melting point apparatus (Yanagimoto Ltd, Kyoto, Japan) and are uncorrected. CI-MS data were measured using a JMS-MS600W spectrometer (JEOL Co. Ltd, Tokyo, Japan). UV and IR spectra were recorded on an Ultrospec 2100 pro UV-visible spectrophotometer (Amersham Biosciences Ltd, Tokyo, Japan) and a JASCO FT/IR-4100 instrument (JASCO Co. Ltd, Tokyo, Japan), respectively. ${ }^{1} \mathrm{H}$ - and ${ }^{13} \mathrm{C}-\mathrm{NMR}$ spectra were recorded using a JEOL Lambda-500 $\left(500.00 \mathrm{MHz}\right.$ for ${ }^{1} \mathrm{H}, 125.25 \mathrm{MHz}$ for ${ }^{13} \mathrm{C}$, JEOL Co. Ltd) and/or a Bruker AV-400 spectrometer $\left(400.13 \mathrm{MHz}\right.$ for ${ }^{1} \mathrm{H}$, $100.61 \mathrm{MHz}$ for ${ }^{13} \mathrm{C}$, Bruker Biospin K. K., Kanagawa, Japan). Chemical shifts $(\delta)$ were measured in ppm using tetramethylsilane as an internal standard. CD curves were determined using a J-820 spectropolarimeter (JASCO Co. Ltd). Column chromatography was performed using Kieselgel 60 (Art. 7734, Merck Ltd, Tokyo, Japan) and Wakogel C-200 (Art. 237-00071, Wako Pure Chemical Industries, Ltd, Osaka, Japan). LPLC was performed using a Chemco Low-Prep 81-M-2 pump (Chemco Scientific Co. Ltd, Osaka, Japan) and a glass column $(200 \times 10 \mathrm{~mm})$ packed with Silica gel CQ-3 $(30-50 \mu \mathrm{m}$, Wako Pure Chemical Industries, Ltd). HPLC was performed using a Senshu SSC-3160 pump (flow rate, $7 \mathrm{ml} \mathrm{min}^{-1}$, Senshu Scientific Co. Ltd, Tokyo, Japan) and a YMC-Pack PEGASIL Silica $60-5$ column $(300 \times 10 \mathrm{~mm}$, YMC Co. Ltd, Kyoto, Japan), equipped with a Shimamura YRD-883 RI detector (Shimamuratech Ltd, Tokyo, Japan). TLC was detected by UV light at $254 \mathrm{~nm}$ and/or by spraying with phosphomolybdic acid (5\%)-ceric acid (trace) in $5 \% \mathrm{H}_{2} \mathrm{SO}_{4}$ and then heating.

\section{Fermentation, extraction and isolation}

Rice (Akitakomachi, $560 \mathrm{~g}$ ) was moisturized with water for $30 \mathrm{~min}$ and then dispensed to four Roux flasks, and sterilized by steaming under pressure. M. filamentosa IFM 41300 was inoculated in these Roux flasks and cultivated at $25^{\circ} \mathrm{C}$ for 21 days, after which the rice was extracted with acetone and the organic layer was evaporated in vacuo. The residue $(42 \mathrm{~g})$ was suspended in water and extracted with AcOEt. The evaporated residue was extracted sequentially with hexane $(100 \mathrm{ml})$, benzene $(100 \mathrm{ml}), \mathrm{CH}_{2} \mathrm{Cl}_{2}(100 \mathrm{ml})$ and $\mathrm{MeOH}(100 \mathrm{ml})$. The benzene extract $(2 \mathrm{~g})$ was chromatographed using a silica gel column (solvent system: $\mathrm{CH}_{2} \mathrm{Cl}_{2}$ /acetone (30:1), (10:1), (5:1), (3:1), (1:1) and acetone) to yield 13 fractions. Fraction 11 (the acetone eluate) was rechromatographed using HPLC with a silica gel $\left(\mathrm{CH}_{2} \mathrm{Cl}_{2} /\right.$ ethanol (8:1)) to give malfilanol A (1: $4.0 \mathrm{mg})$. The hexane extract $(1 \mathrm{~g})$ was chromatographed using a Sephadex LH-20 column (solvent system: hexane/ $\mathrm{CHCl}_{3}$ (1:4) $400 \mathrm{ml}, \mathrm{CHCl}_{3} /$ acetone (4:1) $200 \mathrm{ml},(3: 2) 200 \mathrm{ml}$, and acetone $300 \mathrm{ml})$ to yield nine fractions. Fraction $3\left(\mathrm{CHCl}_{3}\right.$ : acetone $\left.(4: 1), 219 \mathrm{mg}\right)$ was chromatographed using HPLC with a silica gel (hexane/acetone (4:1)) to give malfilanol B (2: $5.0 \mathrm{mg})$.

\section{Malfilanol A (1)}

Colorless amorphous solid. CI-MS $m / z$ (\%): $253.1833\left((\mathrm{M}+\mathrm{H})^{+}, 253.1804\right.$ for $\mathrm{C}_{15} \mathrm{H}_{25} \mathrm{O}_{3}$ ). UV $\lambda_{\text {max }}(\mathrm{MeOH}) \mathrm{nm}(\varepsilon): 218(4.00)$. IR $v_{\max }(\mathrm{KBr}) \mathrm{cm}^{-1}: 3420$, 2945,1690 and 1650. CD (MeOH) $\Delta \varepsilon(\mathrm{nm}):+0.76(249)$ and $-7.72(215)$. $[\alpha]_{\mathrm{D}}{ }^{25}:-96^{\circ}$ (c 0.525, MeOH). ${ }^{1} \mathrm{H}-\mathrm{NMR}\left(\mathrm{CDCl}_{3}\right): \delta 0.86\left(3 \mathrm{H}, \mathrm{s}, 13-\mathrm{H}_{3}\right), 0.96$ $\left(3 \mathrm{H}, \mathrm{s}, 14-\mathrm{H}_{3}\right), 1.05(1 \mathrm{H}, \mathrm{d}, J=15.0 \mathrm{~Hz}, 5-\mathrm{H}), 1.20(1 \mathrm{H}, \mathrm{m}, 2-\mathrm{H}), 1.21(3 \mathrm{H}, \mathrm{s}$, $\left.12-\mathrm{H}_{3}\right), 1.22(1 \mathrm{H}, \mathrm{m}, 3-\mathrm{H}), 1.41(1 \mathrm{H}, \mathrm{m}, 10-\mathrm{H}), 1.46(1 \mathrm{H}, \mathrm{m}, 5-\mathrm{H}), 1.54(1 \mathrm{H}$, td, $J=14.0,9.0 \mathrm{~Hz}, 2-\mathrm{H}), 1.69(1 \mathrm{H}, \mathrm{btd}, J=13.1,2.8 \mathrm{~Hz}, 11-\mathrm{H}), 1.73(1 \mathrm{H}, \mathrm{m}$, 3-H), $1.77(1 \mathrm{H}, \mathrm{dd}, J=13.1,6.7 \mathrm{~Hz}, 10-\mathrm{H}), 2.16(1 \mathrm{H}, \mathrm{m}, 9-\mathrm{H}), 2.40(1 \mathrm{H}, \mathrm{dd}$, $J=18.0,5.8 \mathrm{~Hz}, 9-\mathrm{H}), 2.69(1 \mathrm{H}, \mathrm{m}, 6-\mathrm{H})$ and $6.97(1 \mathrm{H}, \mathrm{dd}, J=5.8,1.2 \mathrm{~Hz}, 7-\mathrm{H})$. ${ }^{13} \mathrm{C}-\mathrm{NMR}\left(\mathrm{CDCl}_{3}\right): \delta 19.6$ (C-10), 25.1 (C-9), 29.3 (C-14), 30.1 (C-12), 31.4 (C-6), 32.0 (C-13), 32.7 (C-4), 34.2 (C-3), 34.5 (C-2), 41.3 (C-5), 48.3 (C-11), $74.2(\mathrm{C}-1), 126.9$ (C-8), 147.8 (C-7) and $172.6(\mathrm{C}-15)$.

\section{Malfilanol B (2)}

Colorless crystalline powder (m.p. $109^{\circ} \mathrm{C}$ ). CI-MS m/z (\%): 267.1950 $\left((\mathrm{M}+\mathrm{H})^{+}, 267.1960\right.$ for $\left.\mathrm{C}_{16} \mathrm{H}_{27} \mathrm{O}_{3}\right)$. UV $\lambda_{\max }(\mathrm{MeOH}) \mathrm{nm}(\varepsilon): 220$ (3.92). IR $v_{\max }(\mathrm{KBr}) \mathrm{cm}^{-1}: 3465,2950,1715$ and $1650 . \mathrm{CD}(\mathrm{MeOH}) \Delta \varepsilon(\mathrm{nm})$ : $+0.80(247)$ and $-4.84(218)$. $[\alpha]_{\mathrm{D}}{ }^{25}:-68^{\circ}$ (c $\left.0.365, \mathrm{MeOH}\right) .{ }^{1} \mathrm{H}-\mathrm{NMR}$ $\left(\mathrm{CDCl}_{3}\right): \delta 0.86\left(3 \mathrm{H}, \mathrm{s}, 13-\mathrm{H}_{3}\right), 0.96\left(3 \mathrm{H}, \mathrm{s}, 14-\mathrm{H}_{3}\right), 1.05(1 \mathrm{H}, \mathrm{d}, J=15.0 \mathrm{~Hz}$, 5-H), $1.19(1 \mathrm{H}, \mathrm{m}, 2-\mathrm{H}), 1.21\left(3 \mathrm{H}, \mathrm{s}, 12-\mathrm{H}_{3}\right), 1.23(1 \mathrm{H}, \mathrm{m}, 3-\mathrm{H}), 1.42(1 \mathrm{H}, \mathrm{m}$, 10-H), $1.45(1 \mathrm{H}, \mathrm{m}, 5-\mathrm{H}), 1.53(1 \mathrm{H}, \mathrm{m}, 2-\mathrm{H}), 1.67(1 \mathrm{H}, \mathrm{btd}, J=12.3,3.3 \mathrm{~Hz}$, $11-\mathrm{H}), 1.73(1 \mathrm{H}, \mathrm{m}, 3-\mathrm{H}), 1.77(1 \mathrm{H}, \mathrm{bdd}, J=12.3,6.9 \mathrm{~Hz}, 10-\mathrm{H}), 2.16(1 \mathrm{H}, \mathrm{m}$, 9- $\mathrm{H}), 2.41(1 \mathrm{H}, \mathrm{dd}, J=18.4,6.0 \mathrm{~Hz}, 9-\mathrm{H}), 2.68(1 \mathrm{H}, \mathrm{bs}, 6-\mathrm{H}), 3.69(3 \mathrm{H}, \mathrm{s}$, $\left.\mathrm{COOCH}_{3}\right)$ and $6.85(1 \mathrm{H}, \mathrm{bd}, J=5.9 \mathrm{~Hz}, 7-\mathrm{H}) .{ }^{13} \mathrm{C}-\mathrm{NMR}\left(\mathrm{CDCl}_{3}\right): \delta 19.6(\mathrm{C}-$ 10), 25.4 (C-9), 29.2 (C-14), 30.0 (C-12), 31.2 (C-6), 32.0 (C-13), 32.7 (C-4), 34.2 (C-3), 34.5 (C-2), 41.5 (C-5), $48.4(\mathrm{C}-11), 51.4\left(\mathrm{COOCH}_{3}\right), 74.0(\mathrm{C}-1)$, $127.5(\mathrm{C}-8), 145.5(\mathrm{C}-7)$ and $168.1(\mathrm{C}-15)$. 
Methylation of malfilanol A (1) with $\mathrm{CH}_{2} \mathrm{~N}_{2}$

An excess ethereal solution $(2 \mathrm{ml})$ of diazomethane was added to an ether solution $(0.5 \mathrm{ml})$ of malfilanol A $(\mathbf{1})(1.0 \mathrm{mg})$, and the solution was stirred for $1 \mathrm{~min}$ followed by evaporation to give malfilanol B (2) $(0.8 \mathrm{mg})$.

\section{Cytotoxicity assay}

Cells were seeded into 96-well microplates at 3000 cells per well, allowed to attach for $4-6 \mathrm{~h}$ and then incubated in Dulbecco's modified Eagle's medium (Invitrogen Co. Ltd, Carlsbad, CA, USA) for A549 human lung cancer cells, or in endothelial cell growth medium-2 Single Quots medium (Lonza Co., Ltd, Valais, Switzerland) supplemented with $10 \%$ fetal bovine serum, penicillin G $\left(100 \mathrm{U} \mathrm{ml}^{-1}\right)$, streptomycin $\left(100 \mu \mathrm{g} \mathrm{ml}^{-1}\right)$ and amphotericin B $\left(0.25 \mu \mathrm{g} \mathrm{ml}^{-1}\right)$ for HUVEC until they were $80 \%$ confluent. The media were supplemented with the indicated concentrations of isolated compounds for 48-72 h. Cell proliferation was measured using the Cell Counting Kit8 (Dojindo, Kumamoto, Japan) to count living cells by combining WST-8 (2-(2-methoxy-4-nitrophenyl)-3-(4nitrophenyl)-5-(2,4-disulfophenyl)-2H-tetrazolium) and 1-methoxy PMS (1methoxy-phenazine methosulfate). ${ }^{6}$ Briefly, after the medium was removed, $10 \mu \mathrm{l}$ of Cell Counting Kit8 solution was added to each well, and the plates were incubated for $4 \mathrm{~h}$, then cell numbers were obtained by scanning with a Bio-Rad Model 550 microplate reader (Bio-Rad Laboratories, Inc., Hercules, CA, USA) at $450 \mathrm{~nm}$.

\section{Antifungal assay using the paper disk method}

The antifungal assay was performed using a method reported earlier. ${ }^{5}$ The antifungal assay was performed using the paper disk method against $A$. niger
IFM 41398, A. fumigatus IFM 41362, C. albicans IFM 40009 and C. neoformans ATCC 90112 as test organisms. Malfilanol A (1) and malfilanol B (2) were applied to the paper disk (diameter: $8 \mathrm{~mm}$ ) at $50 \mu \mathrm{g}$ per disk and the disks were placed on the assay plates. The test organisms were cultivated in potato dextrose agar (Nissui Pharmaceutical Co., Ltd, Tokyo, Japan) at $25^{\circ} \mathrm{C}$. After $48-72 \mathrm{~h}$ of incubation, zones of inhibition (the diameter measured in millimeters) were recorded.

\section{ACKNOWLEDGEMENTS}

We thank Dr H Kasai and Dr M Ikegami of Hoshi University for their technical assistance. This work was supported by an 'Open Research Center' Project from the Ministry of Education, Culture, Sports, Science and Technology, Japan.

1 Udagawa, S. Taxonomical outline of dermatophytes in the Ascomycetes. Jpn. J. Med. Mycol. 38, 1-4 (1997).

2 Hosoe, T. et al. 4-Benzyl-3-phenyl-5H-furan-2-one, a vasodilator isolated from Malbranchea filamentosa IFM 41300. Phytochemistry 65, 2776-2779 (2005).

3 Wakana, D. et al. Structures of new triterpene glycosides, malbrancheoside A-D, from Malbranchea filamentosa. Heterocycles 75, 1109-1122 (2008).

4 Wakana, D. et al. Structures of two new glycosides of furanone derivatives, malfilamentosides A and B, isolated from Malbranchea filamentosa. Mycotoxins 58, 1-7 (2008)

5 Wakana, D. et al. New citrinin derivatives isolated from Penicillium citrinum. J. Nat. Med. 60, 279-284 (2006).

6 Weisskopf, M. et al. A Vitex agnus-castus extract inhibits cell growth and induces apoptosis in prostate epithelial cell lines. Planta Med. 71, 910-916 (2005) 